\title{
Why Traditional Financial Analysis Tools and Approaches are Not Suitable for Municipalities and should be Re-Designed? (The Case of Municipalities in Czech Republic)
}

\author{
Filip Hrůza
}

\begin{abstract}
The public sector has undergone in the 20th century complex development. Part of this evolution was represented by search for suitable management and analysis tools in the research field and in practice. Public sector inspired in this issue by the private sector, when some of its approaches, principles and tools were transformed or directly transferred to its theory and practice. The use and application of business intelligence tools in financial management of public sector entities is one of the themes that still inspires debate regarding the extent of the appropriateness of the application of these instruments into specific conditions and different functioning environment. This article aims to map out the developments in this specific area and to identify the reasons for a re-design or calibration during such transfers.
\end{abstract}

Index Terms-Public sector, municipalities, financial analysis tools, specifics, re-design.

\section{INTRODUCTION}

This article focuses on the development in the period 20th century focusing on the financial dimension of transfer analytical tools between these two entities, public and private sector. Just private sector development in this specific area, which was followed by the public sector, led to the creation of demand for methods and tools suitable for people responsible for operationally and strategically managing the committed economic entities (Manager, Director, Mayor ...). The area of financial management is a very broad theme and the area of financial analysis plays one of major roles.

Economic units in the private and the public sector are not identical, they differ in a number of specificities. In the context of this article it is necessary to mention in what ways it differs due to the different construction or the calibration of applied financial analysis instruments. But first it is desirable to identify the competent bodies in the public sector, which in this case refer to cities and municipalities, provinces or other administrative units with the influence of the State represented by the central government (mostly in the form of subsidies or contributions). State, hence its subordinate bodies are not intended to generate a profit in the long term, but it has to prove to maintain its existence ideally permanent

Manuscript received November 5, 2012; revised January 2, 2013. Thi paper was prepared within the framework of the project of specific research Quality evaluation of public policies in the context of restrictive constraints of public finances. Project code: MUNI/A/0983/2011. Masaryk University.

Filip Hrůza is with the Faculty of Economics and Administration, Masaryk University, Czech Republic (e-mail: 99925@mail.muni.cz). and that is combined with the stable finances. The identified entities in the pursuit of long-term existence are based on the concept of 3E (effectiveness, efficiency, economy). For example, in the Czech Republic is this concept contained in the law, which these specific entities have to follow. However it is very difficult to transform these concepts into specific features of financial management of these entities. Historical context of development in this area and of various instruments brought a fragmentation and absence of common understanding on the areas and indicators, which are able to analyze the financial dimension of mentioned entities perfectly, so the only recognized argument remains that starting point is the concept of 3E [1]. These efforts can be incorporated into the New Public Management direction, which is trying to assess through new frameworks and is based also on models in the private sector, however, this sphere of human society, especially in recent decades has undergone a series of moments, which was to challenge the confidence in it own and in its various analytical tools and thanks to occurrence of bankruptcies, failures and other events in this area, there is a potential space for the creation or upgrading of new instruments [2]. In addition, conditions are constantly changing, but what doesn't change is the willingness to enhance financial performance, sustained efforts are required in improving financial management practices [3].

The aim of this article is to identify the reasons why it is necessary to re-design and calibrate actual concept for use in the public sector through the identification of relevant specifics.

\section{USED MethodS AND Methodology}

To process this article following methods were used: the study of relevant literature, analysis, explanation, deduction and synthesis (used in the identification of partial specifics). The research methodology used is characterized by qualitative research and critical literature preview. Partial research outcome should be relevant discussion of methodological dimensions of financial analytical tools, which can be used for a more detailed further research.

\section{LITERATURE PREVIEW}

The process of transforming the concept of financial analysis (FA) into the functioning of mentioned public sector 
entities can be identified and divided as follows:

1) The application of pure forms of FA tools in the management of the public sector entity (full transfer)

2) The application of FA tools or approaches from the private sector into the public sector entity management with a re-design the structures or the calibration of instruments (transfer and modification)

3) Design of own FA instruments in the public sector entity on the basis of the public sector functioning (own design)

4) Design of own FA instruments in the public sector entity on the basis of the public sector functioning with upgrade by elements of FA tools from the private sector (own design with innovation)

The roots of the financial analysis concept and its greatest development in this direction are visible mainly in the Anglo-American countries (USA, Australia, United Kingdom). In the initial stage of this approach have been the real outcomes of the sectoral statistical averages and one-dimensional discriminatory analysis [4]. Over time, the demand for financial analytical tools increased. In the context of the development of the stock market formed various experimental methods and also there grew up the demand on predictive ability of constructed tools. There also began the change of relevant tools nature from only positive analysis of historical and actual stage of the entity in financial dimension to those capable of a prediction of the future development for certain indicators and the overall stage of entity itself [5].

From a methodological perspective, the analysis of the financial-analytical indicators were identified the following research approaches:

1) The identification of research outcomes through the use of negative aspects on a sample of unsuccessful companies [4]-[5]

2) The identification of research outcomes through comparison of successful and unsuccessful companies [6]

3) The identification of research outcomes through identification of aspects of successfully functioning companies [7]

Further development in this area could be collectively described as the process of swelling, when by further research were invented additional indicators. There were also changing approaches to work and the evaluation of these indicators such as multidimensional discrimination analysis [8]. During further historical development were created many variously designed and oriented tools from elementary analysis of financial ratios, through complex analytical tools to more complex cases (for example: bankruptcy and solvency models, pyramid models or balanced-scorecard models ...).

During the 1990s of the last century in India has been extensive research between Indian municipalities with use of tools from financial analysis and financial management (f.e. cash-flow analysis, financial ratio analysis, liquidity analysis...) [9]. Reforms in New Public Management style are not just a different way of managing and delivering public services, but also different tools and techniques of financial management represented in New Public Financial Management [10]. Dominant approach which came into this area was New Public Financial Management (based on the principles of New Public Management), which was identified by changes in the financial reporting systems (for example, the adoption of accrual principle), as well as in the development of market-oriented management systems, the development of a performance-oriented approaches, decentralization of public budgets and last but not least also by changes in internal and external audits in the public sector [11]. Hand in hand with research efforts went in this direction also some governments, f.e. USA introduced GASB in 1999 , which regulates financial reporting model, inter alia, for the local governments in order to simplify the analysis of the governments overall financial condition and the Financial Trend Monitoring System (FTMS) [12]. Canada and the Canadian Institute of Chartered Accountants (CICA) developed a common framework for concepts such as financial condition and the financial health of public entities [13]. Other solutions in practice include measuring the financial condition of the government of U.S. States through four financial dimensions and 11 specific financial indicators - cash solvency (cash ratio, quick ratio, current ratio), budgetary solvency (operating surplus/deficit ratio, per capita), long-run solvency (net asset ratio, long-term liability ratio, long-term liability per capita) and service level (solvency tax per capita, revenue per capita, expenses per capita) [14], or efforts to construct model capable of prediction of local fiscal distress and the development of analytical methods for municipal financial health [1], [14]-[16].

\section{SPECIFICS IDENTIFICATION}

In the past a number of different solutions were developed. Specific solutions vary from case to case. There exists a common deficiency in some cases, the search for a new solution is based on the existing knowledge but what is usually missing is the identification of specifics distinguishing essence, functioning and conditions of public sector entities from the entities in the private sector. If the goal is to create a relevant and properly functioning financial analysis tool for an entity with its own specifics, you must first understand what is the nature of the organization, how it works and in what environment. The disadvantage of this approach, which has undergone its biggest development mainly in the 20th century, was the absence of an explicit theoretical structure and that its dominant approach was pragmatic empiricism [17]. The concept of financial analysis and its individual tools are by their character and use approaching to signal and monitoring models and concepts that have been developed for the private sector, but there are also the transformation to public sector entities, in this case of cities and municipalities [18]-[20]. Some models identified as important variables for signal and monitoring models debt government Employees, type of government, population, company town and the level of political competition [21]-[23].

In the following part of this article is performed the identification of specifics distinguishing public sector and private sector in terms of financial management and analysis. In connection with this there are listed certain implications of 
these differences for the creation of a specific financial-analysis tool.

\section{A. Character of the Market and the Position of the Subject on it}

In the past was proved on individual cases different behavior of profitability by the industry concentration depending on the size of the company or that profitability rate grows with the size of the entity within the industry [24]-[25]. Different economic entities representing the State (in these case municipalities) in some cases act as a monopoly, oligopoly, or a company with a dominant market position. According to economic theory these entities produce their goods and services at different price, amount and costs than if they were operating on a perfectly competitive market. There are various studies examining different behavior and functioning of these structures [26]-[27]. This aspect should be taken into account and reflected in the construction of specific tools for public sector entities.

\section{B. Differentiation and Specification of Cost and Profit Centers}

While in private companies is the main criterion profit and the main goal its maximization, in public sector entities this simple mechanism and related incentives are lacking. Another used argument is that the entity is the only provider of goods or services. However, competition in this case can be replaced by industry comparisons (f.e. best practice). Moreover, there are areas such as the economic activities of the municipality, where can be promoted the principles mentioned in the private sector, if the selected activity does not belong to the priorities of municipal politics (f.e. housing for selected groups). Division of the public sector entity in activities where you can watch the profit criterion is necessary in terms of the use of financial analysis. Implementation of this aspect in the financial analysis of public sector entity can contribute to increase efficiency. Relevant analytical tools should be able to perceive this dimension.

\section{Differentiation of the Nature of Financial Flows}

Entities in different sectors of the economy have different behavior and management of financial flows and processes inside based on their specifics. Even in the private sector in terms of analysis there are specific differences between sectors (services, production, finance). This aspect should be taken into account before the application for public sector entities analytical tools. This can be shown on liquidity of different sector entities. From own experience in case of Czech municipalities can be listed cases from the whole spectrum of liquidity and exception cases are certainly not municipalities with high liquidity because of holding high cash on current accounts as a result of surpluses from previous years. But for example this area of financial management is not seized from a research point of view and there are remaining many open questions unanswered.

\section{Differences in the Sectoral Specifics}

Financial analysis tools should be able to reflect these differences if they aim to function effectively. Therefore it is important to know well the nature, activities and patterns according to which the reference entity operates. This is not quite possible to capture in quantitative research approach, but there is potential space for individualizing or adapting some form of calibration and further qualitative research. It is desirable to engage and perceive additional information relating to sectoral specifics that distinguish conditions in different industries and have different effects on the course of financial management and processes such as financial distress or bankruptcy [28].

\section{E. Suitability of Data Bases in the Design and Calibration of Tools}

Financial analysis tools tend to be deduced on the basis of historical data and testing. Therefore, it is important to consider the nature of the tested sample, because on its basis are subsequently concluded normative conclusions, but also a different time period in which the samples were monitored must be taken in account. A weakness of this approach is the lack of relevant testable theory and most of the tools and methods are created primarily based on specific practical needs [17]. For example, some of mentioned tools depend on the authority and presentation of the author's experience knowledge. Traditional tools of financial analysis were constructed and calibrated in the past especially for data base consisting of private companies. Thus, there has been rising question of the applicability of the instrument in a specific environment of the public sector. However the existing research shows that in terms of functionality of financial analysis tools is necessary to take into account other distinguishing aspects. For example, an aspect of the analyzed entity size in relation to the functionality characteristics due to the bankruptcy prediction when it was pointed out that for larger entities it is needed fewer parameters than for smaller in terms of analysis [29]. Important is also the structure of the sample, when analyzing the entities in a different state of functioning as coefficient bias or distortions may be due to the excesses of certain samples in the data set at the expense of others (f.e. more bankrupt municipalities in data set may distort analytical information when representation rate does not reflect the normal situation in society) [30]. Another elementary problem is that the existing relevant studies and experience are mainly based on analysis of entities budgets (general fund), but this reflects only part of the overall financial management of the entity [1]. However, the financial dimension of cities and municipalities is more than just a budget. If we want to affect the financial dimension of the whole entity, it is necessary to include in the analysis entity as a whole.

\section{F. The Structure of the Balance Sheet of Analyzed Entities}

This aspect relates to the structure of the assets of the entity, which is subject to certain selected indicators of financial analysis tools. If you stand facing each other private companies from various sectors, asset structure is different and their relationships as well. In previous studies it was proved for example on a sample of 3500 SME companies in the UK positive relation of long-term debt to asset structure and negative relationship of short-term debt to asset structure and profitability [31]. There was also found significant 
differences across industries in most of the explanatory variables. It was then pointed out that the optimal capital structure choice can be influenced by factors such as growth, cash flow, size and product and industry characteristics [32]. It was also demonstrated in the research significant difference in the capital structure depending on the industry where the company operates [33]. Cities and municipalities are largely focused on financial transfers (f.e. payment of benefits, procurement, payments for maintenance of property), which directly affects the balance sheet, profit and loss account and cash flow statement. The structure of assets in the case of cities and municipalities also differ from private companies and identification of its specifics should be the subject of further research. These and other aspects should be taken into account in the search for appropriate forms of financial analysis tool.

\section{G. The Character of Revenues}

In the case of Czech cities and municipalities comes large share of their revenues from tax revenues, but the administration and management is in the hands of the central government and municipalities can influence them only indirectly. In terms of the purpose of financial analysis concept for financial management of mentioned entities is the difference between the entities that have the ability to directly affect their revenue actively and those who can not directly manage substantial part of their revenues. This aspect should be reflected in the design of relevant analytical tool.

\section{H. Time Aspect of Tested Data Sample}

This argument has been used to defend the creation of new model ZETA [34]. An important prerequisite for an appropriate data sample is its relevance to actual conditions. Relevance of tested samples in time decreases if conditions change and the explanatory power of analysis decline. If the independent variables are not stable over time, the results can be confusing [35], [36]. For the best performing financial analytical tool it is necessary to incorporate relevant elements which take into account actual conditions in which the entity actually operates.

\section{The Return on Assets}

In the private sector is one of the relevant indicators of return on assets (ROA). Is this concept transferable and desired to function in the public sector practice in certain form? Relevant Czech laws imposes the duty of $3 \mathrm{E}$ in municipality management, which is related to the basic principles of ROA indicator in the general level. But while in the private sector has asset a potential of return, in case of municipalities are certain assets which, for some reason does not have return as the primary criterion (f.e. social housing, public green). In addition, however, there is community property for which it makes sense to achieve profitability (f.e. rent commercial space, rental of advertising space). This aspect should be reflected in some way to the structure of suitable financial analysis tool.

\section{CONCLUSION}

This paper attempted to identify the main areas, aspects and elements that should be taken into account when considering the appropriate financial analytical tools and should be the subject to further research in regard to understanding their relationship to the financial analysis concept. The paper also was to create a discussion on this issue and its potential solutions. The main message of this conclusion should be that the identification of different specifics should serve as a starting point for further research in the area of finding suitable tools of financial analysis for the public sector entities. It would be appropriate to pay attention to individual specifics, their effect on the specific form of adjustment of financial analysis and its subsequent functioning.

\section{REFERENCES}

[1] X. Wang, L. Dennis, and Y. S. Jeff, "Tu. Measuring Financial Condition: A Study of U.S. States," Public Budgeting and Finance, vol. 27, no. 2, pp. 1-22, 2007

[2] M. Conceição. The Role of Auditing in the Public Sector. [Online]. Available:

http://www.mngt.waikato.ac.nz/ejrot/cmsconference/2005/proceeding s/criticalaccounting/DaConceicao.pdf

[3] O. Olson, J. Guthrie, and C. Humphrey, "International Experiences with New Public Financial Management (NPFM) Reforms: New World? Small World? Better World? In O. Olson, J. Guthrie and C. Humphrey (Eds.)," Global Warning! Debating International Developments in New Public Financial Management, pp. 17-48, 1998

[4] W. H. Beaver, "Financial ratios as predictors of failure," Empirical Research in Accounting: Selected Studies, University of Chicago, pp. 71-111, 1966.

[5] R. F. Smith and A. H. Winakor, A Test Analysis of Unsuccesful Industrial Companies, Bulletin No. 31, University of Illinois, Bureau of Business Research, 1930.

[6] P. J. Fitzpatrick, "A Comparison of the Ratios of Succesful Industrial Enterprises with Those of Failed Companies," The Accountants Publishing Company, 1932.

[7] C. H. L. Merwin, Financial Characteristics of American Manufacturing Corporations, Washington. U.S. Government Printing Office, no. 15, pp. 442, 1940.

[8] E. I. Altman, Financial Ratios, Discriminant Analysis and the Prediction of Corporate Bankruptcy, the Journal of Finance, vol. 23, 1968.

[9] R. Joshi, Financial Management in Municipalities, Urban India, vol. 16, no. 2, 1996.

[10] E. Padovani, R. L. Orelli, and G. Farneti. (2010). Accounting Reforms and Financial Health: Which Effects on Municipal Governments? The Case of Italy. [Online]. Available: http://ssrn.com/abstract=1612321

[11] J. Guthrie, O. Olson, and C. Humphrey, "Debating developments in new public financial management: The limits of global theorising and some new ways forward," Financial Accountability and Management, vol. 15 , no. $3-4$, pp. 209-228, 1999.

[12] GASB, Statement of the Governmental Accounting Standards Board No. 34: Basic Financial StatementsFand Management's Discussion and AnalysisFfor State and Local Governments, Norwalk, CT: GASB, 1999; GASB, Statement No. 44, Norwalk, CT: GASB, 2004.

[13] Canadian Institute of Chartered Accountants, Public sector statements of recommended practice (SORP) 4. Indicators of financial condition. Toronto, Ontario, Canada: CICA, 2009.

[14] S. M. Groves, W. M. Godsey, and M. A. Shulman, "Financial indicators for local government," Public Budgeting and Finance, vol. 1, no. 2, pp. 5-19, 1981.

[15] P. Kloha, C. Weissert, and R. Kleine, "Developing and Testing a Composite Model to Predict Local Fiscal Stress," Public Administration Review, vol. 65, no. 3, pp. 313-323, 2005.

[16] R. Cabaleiro, E. Buch, and A. Vaamonde. (2012). Developing a Method to Assessing the Municipal Financial Health. The American Review of Public Administration. [Online]. Available: http://arp.sagepub.com/content/early/

[17] J. O. Horrigan, "A Short History of Financial Ratio Analysis," The Accounting Review, vol. 43, no. 2, pp. 284-294, 1968.

[18] M. J. Flannery, Asymmetric Information and Risky Debt Maturity Choice, Journal of Finance, vo. 41, pp. 19-37, 1986. 
[19] S. A. Ross, The Determination of Financial Structure: The Incentive-Signalling Approach, Bell Journal of Economics, vol. 8, pp. 23-40, 1977.

[20] J. H. Evans and J. M. Patton, Signaling and Monitoring in Public-Sector Accounting, Journal of Accounting Research, vol. 25, pp. 130-158, 1987.

[21] W. R. Baber and P. K. Sen, The role of Generally Accepted Reporting Methods in the Public Sector: An Empirical Test, Journal of Accounting and Public Policy, vol. 3, pp. 91-106, 1984.

[22] R. W. Ingram, Economic Incentives and the Choice of State Government Accounting Pracitces, Journal of Accounting Research, pp. 126-144, 1984.

[23] J. L. Zimmerman, The Municipal Accounting Maze: An Analysis of Political Incentives, Journal of Accounting Research, pp. 107-144, 1977.

[24] H. Demsetz, Industry Structure, Market Rivalry, and Public Policy, Journal of Law and Economics. University of Chicago Press, vol. 16, no. 1, pp. 1-9, 1973.

[25] W. G. Shepherd, "The elements of market structure," Review of Economics and Statistics, vol. 54, no. 1, pp. 25-37, 1972.

[26] A. Nishimori and H. Ogawa, "Public Monopoly, Mixed Oligopoly and Productive Efficiency," Australian Economic Papers. vol. 41, Issue 2, pp. 185-190, June 2002.

[27] A. Herr, "Quality and Welfare in a Mixed Duopoly with Regulated Prices: The Case of a Public and a Private Hospital," German Economic Review, vol. 12, Issue 4, pp. 422-437, 2011.

[28] N. T. Hill, S. E. Perry, and S. Andes, Evaluating Firms in Financial Distress: An Event History Analysis, Journal of Applied Business Research, vol. 12, no. 3, pp. 60-71, 1996.

[29] R. O. Edmister, An Empirical Test of Financial Ratio Analysis for Small Business Failure Prediction, The journal of Financial and Quantitative Analysis, vol. 7, no. 2, pp. 1477-1493, 1972.
[30] M. E. Zmijewski, Methodological Issues Related to the Estimation of Financial Distress Prediction Models, Journal of Accounting Research, vol. 22, pp. 59-82, 1984

[31] G. Hall, P. Hutchinson, and N. Michaelas, Industry Effects on the Determinants of Unquoted SMEs' Capital Structure, International Journal of the Economics of Business, vol. 7, Issue 3, 2000.

[32] S. N. Bhaduri, "Determinants of capital structure choice: A study of the Indian corporate sector. Applied Financial Economics," vol. 12, Issue 9, 2002.

[33] M. Talberg, C. H. Winge, S. Frydenberg, and S. Westgaard, Capital Structure across Industries, International Journal of the Economics of Business. vol. 15, Issue 2, 2008.

[34] E. Altman, R. Haldeman, and P. Narayanan, ZETA Analysis: A New Model to Identify Bankruptcy Risk of Corporations, Journal of Banking and Finance, June 1977.

[35] Y. M. Mensah, An Examination of the Stationary of Multivariate Bankruptcy Predictive Models: A Methodological Study, Journal of Accounting Research, vol. 22, no. 1, pp. 380-395, 1984.

[36] C. Zavgren, The Prediction of Corporate Failure: The State of the Art, Journal of Accounting Literature, vol. 2, pp. 1-35, 1983.

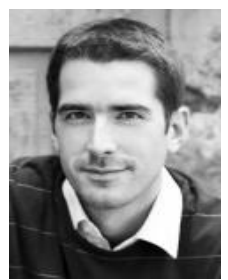

Filip Hrůza is currently a PhD student at the Faculty of Economics and Administration, Masaryk University, Czech Republic. He earned Master Degree in 2009 in Public Economics at the Faculty of Economics and Administration, Masaryk University. He studied at Tampere University of Applied Sciences (Finland) for one semester as undergraduate on Erasmus program. He attended an internship at the Ministry of Finance Czech Republic for five month in 2008. His main areas of academic and research interest are public finances, public financial management and local governance. 